\title{
Challenges And Strategies For The Improvement Of Water Management In Bhopal
}

\author{
Kavita Dehalwar \\ Dr. Jagdish Singh
}

Architecture and Planning Department, Maulana Azad National Institute of

Technology (MANIT), Bhopal, M.P. INDIA.

doi: 10.19044/esj.2016.v12n2p207 URL:http://dx.doi.org/10.19044/esj.2016.v12n2p207

\begin{abstract}
Bhopal is gradually being transformed into a metropolitan city due to its high developmental trajectory and its vast population size. Although she has earned the reputation of 'City of Lake' owing to her large number of ponds and lakes, she is insufficient in catering for the ever growing needs of her entire populace. Many natural and anthropogenic activities and occurrences such as unplanned infrastructural development, short- lived rainfall coupled with inefficient management of solid waste as well as inadequacy in skilled-manpower, are all responsible for this. In the current scenario, strategies such as the employing of technical-know-how and the engaging of Community Based Organizations are being utilized for the managing of this problem. Other invaluable efforts for the building of the social capital would be needed for the enlargement of the government's reach in order to install the effective sustainable water management.
\end{abstract}

Keywords: Solid Waste, Pollution, Community Based Organizations, Manpower

\section{Background of Research}

Overview of the Challenges faced by the Water Management System (with Special Reference to Bhopal)

Out of the many challenges that are continuously becoming the causes for high concerns, accessibility of most of the global population to healthy water has become one of the domineering issues for all regional, national, and international policy institutions on public health. This has been more so especially in the case of developing countries, in general and India in particular, which is relentlessly trying to get enrolled in the list of the developed nations, This is because these countries do not possess enough resources, advanced technologies, skilled manpower, and most importantly 
financial prowess in the effective management of water resources. India, which has earned the recognition of becoming one of the most populous countries all over the world, is making strenuous efforts in providing clean water to all areas, both rural and urban. Metropolitan centres and other capital cities such as Bhopal, that are in the transition of becoming metropolitan due to their provision of improved urbanized infrastructure coupled with multiple ways to earn high livelihood to the people, are struggling to provide water, and healthy life to all strata of its population. Many residents of Bhopal still lack access to clean drinking water that comes under the jurisdiction of Bhopal Municipal Corporation (BMC). However, the quantity of water that is provided by the private hand pumps, and bore wells to them, more often than not, is highly polluted by chemical, and other toxic materials (Toogood \& Häberli, 2009).

Currently, the water supply system in Bhopal is facing several different problems such as poor maintenance of the water tankers and surfaced pipes that refills the plastic water tanks, ruptured underground surfaced pipes at many points causing wastage of water by a heavy outflow in local areas, and irregular supply through water trucks (Toogood \& Häberli 2009). In summer seasons, most of the wells in the cities cannot supply water on a regular basis because of the over extraction of underground water. Although efforts are being made by the government of Madhya Pradesh in collaboration with other bodies such as United Nations Human Settlement Program (UN-HABITAT), The Energy and Resources Institute (TERI) as well as other civil societies such as 'Samarthan' in finding the practical and pragmatic policy measures, more intense efforts would be required including the participation of other agents such as the citizens especially the affected communities, women and so on. Thus, this would help in improving the current conditions of the population of Bhopal.

\section{Strategies Adopted by the Government's Civil Agencies, NGOs and Private Agents to Check the Constraints of Effective Water Management System in Bhopal}

Several strategies are being adopted in order to upgrade the quality of water and to improve the accessibility of a large proportion of the population of the city to a healthy water supply by the city's civil agencies in cooperation with other agents. Chief among them is the payment royal industries have to make before they are permitted to use underground water coupled with other rules and regulations made by the governmental departments responsible for managing water resources; establishing of colonies including Developing Authorities and Housing Boards for the supply of water by tube walls until unless that colony come under the jurisdiction of municipal body; installment of filtration plant where water is 
being sourced through dams, ponds, and reservoirs; and revising the charges for water connection in accordance with the diameter of pipe used in water supply and the type of user (Khanna \& Khanna, 2006). Consequently, it also include the initiation of effective partnership between municipal corporation of Bhopal with other entrepreneurs, Community Based Organizations (CBOs), and civil societies for curbing the water inaccessibility in colonies and towns of Bhopal(UN-HABITAT 2007)

\section{Aims and Objectives of the Study}

- To explore the challenges faced by various responsible bodies such as civil agencies, NGOs, private players, and individuals in the maintenance of water management in Bhopal.

- To determine the strategies initiated by these bodies in checking those challenges.

- To determine individual level initiatives taken by residents in contributing towards water management in the area.

\section{Research Methodology}

Use of the appropriate research methodology is one of the prerequisite conditions for achieving accurate results in attaining the above mentioned aims and objectives. The study involves quantitative and qualitative analysis wherein quantitative analysis are carried out through, statistical tool of SPSS (Version 21.0) developed by IBM. This tool is used to find the correlation between the strategies adopted by responsible bodies and its effect on water management of the city. With references to the primary data collection, two procedures were applied namely; the conducting of interviews through open-ended questionnaire (qualitative) based on the challenges existing in water management system of Bhopal with the officials who are engaged in distribution network of water supply in four civil agencies such as Bhopal Municipal Corporation (BMC), Public Health and Engineering (PHE), Town and Country Planning Organization (TCPO), and Kolar Road Municipality (KLM). In addition, a survey was conducted on 5000 residents of Old Bhopal and Kolar Road area of the city. This survey explores the strategies adopted by inhabitants and various responsible bodies such as BMC, PHE, TCPO alongside NGOs and private suppliers through the distribution of closed-ended questionnaire. In conducting the survey as well as the interviews, respondents have been selected on the basis of probability and non-probability sampling method. The validity of questionnaire has been tested through Cronbach Alpha using SPSS tool.

The entire research analysis have been spearheaded using three major approaches namely; descriptive: wherein profile and general background of the 5000 respondents have been analyzed; inferential: 
wherein specific information based on responses have been analyzed through testing the hypothesis; and lastly, exploratory: wherein responses of the government representatives have been analyzed, shedding light on the challenges faced by them in the process of water management. In addition, secondary data has also been explored which includes eminent journals, books, government reports, research studies conducted by NGOs and such others, which act as supporting pillars to the primary data analysis.

\section{Findings}

\section{Qualitative Analysis}

Profile of Officials

Ten respondents approach were engaged in the four governmental agencies, namely: BMC, TCPO, PHE, and Kolar Road Municipality (KLM). However, Mr. L and Ms. T belong to Bhopal Metropolitan Council (BMC); Mr. B works with Kolar Road Municipality (KLM) where he supervises the distribution of water network, along with Ms. Q; Mr. A and Ms. P work as engineers with governmental civil agencies such as Town and Country Planning Organizations (TCPO); while Mr. O is entitled to look after the effective management of flood in Public \& Health Engineering (PHE) along with Mr. C Mr. Furthermore, M and Ms. K are employed in the Kolar Road Municipality (KLM). Owing to limited content of journals, excerpts of some of the officials have been mentioned.

\section{Exploratory Analysis: Challenges of Water Management \\ Challenges in the Execution of Water Management Operation}

There are many challenges in the execution of various projects meant for water management system. In consonance with the opinion of $\mathrm{Mr}$. O, "seasonality of water resources" whether sources belong to public or private "affects the availability of water". In all the big cities of Madhya Pradesh, all water resources have dried up, or have come under severe stress due to long drought starting from the year 2002-2003 (Khanna \& Khanna, 2006). Furthermore, other serious concerns for improving the water availability are, "presence of high degree of fluorides" existing in the available water resources because of industrial, municipal, and agriculture pollution in addition to unplanned infrastructural establishments in the city that hinders the natural flow of water streams pointed out by Mr. Q and Mr. A. The Bhoj Wetlands are also facing two problems namely, "poor water quality, and reduced storage capacity" due to the problem of siltation, stated by Mr. M. The quality of water is further getting affected by the inflow of sewage and solid waste in the catchment area of both lakes, expressed Mr. O. Thus, this has also been supported by the study of Bhoj Wetlands (Buric \& Gault, 2011). 


\section{Failure in Water Management System}

Responses of the participants unanimously pointed out that there are many reasons which are continuously affecting the installment of effective water management system in the city. Almost 90\% respondents have the opinion of "inadequacy of skilled-man power which is required to run the projects" that demand high technical qualifications. In addition to it, "high operational and maintenance cost of the projects" which are running at present in the city also acts as an "impediment in bringing about the required economy and efficiency" in the establishment of effective water management system, pointed out Mr. B. Another important issue in this dimension is that there is a mismatch in the demand and supply of water because of the lack of "coordination in various departments" engaged in water supply. This is coupled with the restraints involved in "budgetary allocation" for this gigantic task, and requirement of high expertise on the part of officials engaged in water supplying task, asserted Mr. L.

\section{Quantitative Analysis}

\section{Demographic Profile of Respondents}

Respondents who participated in the survey have varied features in accordance with their different educational standards, occupation, and age group. $71 \%$ of the respondents belonged to the age group of 30 to 50 years. The rest of the respondents either belonged to the age group between 18 to 28 years or are elders who had crossed their 50s. In the same way, female respondents of different age groups and educational qualifications have participated in this survey. Out of $44 \%$ female, $27.7 \%$ were graduates, $10 \%$ were doctoral candidates, and the rest were housewives.

\section{Inferential Analysis}

In this section, testification of hypothesis will be conducted using the Bivaraite Correlation and Linear Regression analytical model. This is achieved by employing the statistical software SPSS developed by IBM.

Research Hypothesis1: Individual initiatives undertaken by residents have no contribution towards water management of their areas.

In order to know the impact of individual level initiatives on the water management, two factors have been chosen. First is the different individual initiatives contributed in sustainable water management. The Pearson Correlation of initiatives like turning off water while brushing, projected a value of $\alpha=0.803$ with significance level 0.000 . Also, very conservative use of water during bath reflected the value of $\alpha, 0.847$, with significance level 0.000 . Second factor that was kept in the consideration is factual knowledge and skills of residents involved in water management system. This parameter projects high value of correlation coefficient 
$\alpha=0.947$ with significance level of 0.000 .Thus, inference can be drawn from the above analysis that there is a significantly positive correlation between individual initiatives and its impact on water management of respective area.

Outcome: Positive correlation between individual level initiative and water management system of Bhopal that nullifies the assumed hypothesis.

Research Hypothesis 2: Strategies initiated by various stakeholders of water management are not effective in meeting the challenges.

Three governmental bodies have been taken into consideration, namely; BMC, PHE, and TCPO. Thus, they are used in measuring the impact of strategies undertaken by these agencies on sustainable water management. By considering the role of BMC on water management as dependent variable, control of scarce water resources, installation of water treatment plant, and irrigation resources management shows the value of $\alpha=0.909$, $\alpha=0.876$, and $\alpha=0.872$ with significance level of 0.000 respectively. In the same way, the roles of PHE and TCPO have been assessed. With regards to $\mathrm{PHE}$, the total population under coverage with respect to sanitation program was depicted $(\alpha=-0.866, p=0.000)$. Also, the role of PHE in tackling the problem of water quality in affected population was shown ( $\alpha=-0.869, p=0.000)$. Thus, this means that concerned department is not able to meet its responsibilities which are related to the distribution of water. The Pearson Correlation for the department TCPO against the independent variables such as operation and maintenance of water supply, solid waste, and sanitation shows moderate correlation $\alpha=0.367, \alpha=0.637$, and $\alpha=0.385$. Therefore, this denotes that the department fulfills its duties related to the operation and maintenance of water supply, sanitation, and waste water management on an average basis. While measuring the impact of private players and civil societies, independent variables such as provision of adequate water supply to each household, even distribution of water to each family have been taken into consideration. It has been found that there is a high correlation of $\alpha=0.430, \alpha=0.300$, with significance level of 0.000 . Therefore, this shows that the strategies adopted by these bodies have a significant impact on the water resources management system of Bhopal.

Outcome: On the basis of the above analysis, this inference can be drawn that the performance of governmental agencies impacts the water level management. Hence, assumed research hypothesis stands nullified.

\section{Findings}

Bhopal is in the phase of transition to becoming a metropolitan city in India due to high level of urbanization and industrialization. This rapid pace of industrialization is resulting in the high demands of water resources and 
enhanced level of environmental stress that further accentuates the scarcity of available resources due to high industrial and agricultural pollution. Although Bhopal has plenty of water bodies and is popularly known as 'City of Lake', but the city's administration is getting unsuccessful in catering for the ever increasing demands of the city's population due to several reasons (Suman \& Kanti, 2014). Therefore, to cater for the needs of the citizens of Bhopal, its administration is taking the recourse of other strategies such as reaching out to alternative resources like collaboration with private contractors and employing advanced technologies in maintaining the existing water resources. Despite making intense efforts to reduce the problem of water scarcity, certain challenges and problems are there. Among them include 'Over Exploitation of Water Resources', 'Institutional and Governance Deficit', and 'Inadequacies of skilled-manpower', that curtail the management prowess of the city's administration and hence demand urgent attention ( Das, 2012). Therefore, in addition to these efforts, it is required to build up social capital by constructing a healthy partnership between community organizations such as Farmers Organizations (FOs), and women centered Self Help Groups for augmenting the capabilities of governance.

\section{References:}

Buric \& Gault, 2011. Natural Resources Management and Environment Department:Land and Water Division, Rome.

Das, K., 2012. Drinking Water and Sanitation in Rural Madhya Pradesh: Issues and Challenges for Policy. Journal of Rural Development, 31(3), pp.287-304.

Khanna, A. \& Khanna, C., 2006. Water and Sanitation in Urban Areas of Madhya Pradesh, New Delhi.

Suman \& Kanti, 2014. Water Quality Management of water resources of Bhopal City: Challenges and Scope. International Research Journal of Environment Sciences, 3(3), pp.22-26.

Toogood \& Häberli, 2009. Analysis of chemical contaminants in groundwater of communities surrounding UCIL plant site in Bhopal, Brighton.

UN-HABITAT, 2007. Community Managed System for Operation, Billing \& Collection of Water Charges, Bhopal. 


\section{APPENDIX 1: CORRELATION TABLES}

\begin{tabular}{|c|c|c|}
\hline & & $\begin{array}{c}\text { Do you contribute to sustainable } \\
\text { water management initiative in } \\
\text { your area? }\end{array}$ \\
\hline \multirow{3}{*}{$\begin{array}{l}\text { Do you contribute to sustainable water } \\
\text { management initiative in your area? }\end{array}$} & Pearson Correlation & 1 \\
\hline & Sig. (2-tailed) & \\
\hline & $\mathrm{N}$ & 5000 \\
\hline \multirow{3}{*}{ I turn off the water while brushing } & Pearson Correlation & $.803^{* *}$ \\
\hline & Sig. (2-tailed) & 0.000 \\
\hline & $\mathrm{N}$ & 5000 \\
\hline \multirow{3}{*}{$\begin{array}{l}\text { I use water conservatively while taking } \\
\text { my bath }\end{array}$} & Pearson Correlation & $.847^{* *}$ \\
\hline & Sig. (2-tailed) & 0.000 \\
\hline & $\mathrm{N}$ & 5000 \\
\hline \multirow{3}{*}{$\begin{array}{l}\text { I try to avoid littering nearby lakes and } \\
\text { save the aquatic habitat }\end{array}$} & Pearson Correlation & $.762^{* *}$ \\
\hline & Sig. (2-tailed) & 0.000 \\
\hline & $\mathrm{N}$ & 5000 \\
\hline \multirow{3}{*}{ I avoid the practice of water wastage } & Pearson Correlation & $.709^{* *}$ \\
\hline & Sig. (2-tailed) & 0.000 \\
\hline & $\mathrm{N}$ & 5000 \\
\hline \multirow{3}{*}{$\begin{array}{c}\text { I like to preserve the rain and fresh } \\
\text { water which is helpful during our } \\
\text { household chore }\end{array}$} & Pearson Correlation & $.819^{* *}$ \\
\hline & Sig. (2-tailed) & 0.000 \\
\hline & $\mathrm{N}$ & 5000 \\
\hline \multirow{3}{*}{$\begin{array}{l}\text { I always repair the leaky faucets in the } \\
\text { home within minimum time }\end{array}$} & Pearson Correlation & $.799^{* *}$ \\
\hline & Sig. (2-tailed) & 0.000 \\
\hline & $\mathrm{N}$ & 5000 \\
\hline \multirow{3}{*}{$\begin{array}{c}\text { I have been a participant in sustainable } \\
\text { water management program and have } \\
\text { assisted the group in water level } \\
\text { monitoring }\end{array}$} & Pearson Correlation & $.598^{* *}$ \\
\hline & Sig. (2-tailed) & 0.000 \\
\hline & $\mathrm{N}$ & 5000 \\
\hline
\end{tabular}

Correlation Table of BMC

\begin{tabular}{|c|c|c|}
\hline & & $\begin{array}{c}\text { Roles of Bhopal } \\
\text { Municipal Corporation }\end{array}$ \\
\hline \multirow{3}{*}{ Roles of Bhopal Municipal Corporation } & Pearson Correlation & 1 \\
\hline & Sig. (2-tailed) & \\
\hline & $\mathrm{N}$ & 5000 \\
\hline \multirow{3}{*}{$\begin{array}{l}\text { Ensures the provision of pure water (for drinking } \\
\text { purposes) with appropriate flow pressure }\end{array}$} & Pearson Correlation & $.722^{* *}$ \\
\hline & Sig. (2-tailed) & 0.000 \\
\hline & $\mathrm{N}$ & 5000 \\
\hline \multirow{3}{*}{ Control the scarce water resources } & Pearson Correlation & $.909^{* *}$ \\
\hline & Sig. (2-tailed) & 0.000 \\
\hline & $\mathrm{N}$ & 5000 \\
\hline \multirow{3}{*}{ Ensures adequate water supply for domestic use } & Pearson Correlation & $.423^{* *}$ \\
\hline & Sig. (2-tailed) & .000 \\
\hline & $\mathrm{N}$ & 5000 \\
\hline \multirow{3}{*}{$\begin{array}{l}\text { Construction of irrigation structures in irrigation } \\
\text { areas }\end{array}$} & Pearson Correlation & $.876^{* *}$ \\
\hline & Sig. (2-tailed) & 0.000 \\
\hline & $\mathrm{N}$ & 5000 \\
\hline
\end{tabular}




\begin{tabular}{|c|c|c|}
\hline \multirow{2}{*}{$\begin{array}{c}\text { Appropriate water allocation to each household in } \\
\text { the locale }\end{array}$} & Pearson Correlation & $.264^{* *}$ \\
\cline { 2 - 3 } & Sig. (2-tailed) & .000 \\
\cline { 2 - 3 } & $\mathrm{N}$ & 5000 \\
\hline \multirow{3}{*}{$\begin{array}{c}\text { Construction of water treatment plant } \\
\text { Increased productive efficiency related to water } \\
\text { usages (e.g. agriculture, irrigation) }\end{array}$} & Pearson Correlation & $.872^{* *}$ \\
\cline { 2 - 3 } & Sig. (2-tailed) & 0.000 \\
\cline { 2 - 3 } & $\mathrm{N}$ & 5000 \\
\cline { 2 - 3 } $\begin{array}{c}\text { Infrastructural development (rainwater harvesting, } \\
\text { prevention of flood, for example) }\end{array}$ & Sig. (2-tailed) & $.553^{* *}$ \\
\cline { 2 - 3 } & $\mathrm{N}$ & 0.000 \\
\cline { 2 - 3 } & Pearson Correlation & 5000 \\
\cline { 2 - 3 } & Sig. (2-tailed) & $.596^{* *}$ \\
\hline \multicolumn{2}{|c|}{$* *$ Correlation is significant at the 0.01 level (2-tailed). } \\
\hline \multicolumn{2}{|c|}{} \\
\hline
\end{tabular}

Correlation Table of PHE

\begin{tabular}{|c|c|c|}
\hline & & $\begin{array}{c}\text { Roles of Public Health } \\
\text { Engineering Department in } \\
\text { Water supply and management }\end{array}$ \\
\hline \multirow{3}{*}{$\begin{array}{c}\text { Roles of Public Health Engineering Department in } \\
\text { Water supply and management }\end{array}$} & $\begin{array}{c}\text { Pearson } \\
\text { Correlation }\end{array}$ & ( \\
\hline & Sig. (2-tailed) & \\
\hline & $\mathrm{N}$ & 5000 \\
\hline \multirow{3}{*}{$\begin{array}{l}\text { Full coverage of both rural and urban population } \\
\text { with safe drinking water supply facilities }\end{array}$} & $\begin{array}{c}\text { Pearson } \\
\text { Correlation } \\
\end{array}$ & $.913^{* *}$ \\
\hline & Sig. (2-tailed) & 0.000 \\
\hline & $\mathrm{N}$ & 5000 \\
\hline \multirow{3}{*}{$\begin{array}{l}\text { Coverage of urban and rural population with } \\
\text { sanitation, up to the limit determined by the GOI, } \\
1981\end{array}$} & $\begin{array}{c}\text { Pearson } \\
\text { Correlation }\end{array}$ & $-.869^{* *}$ \\
\hline & Sig. (2-tailed) & 0.000 \\
\hline & $\mathrm{N}$ & 5000 \\
\hline \multirow{3}{*}{$\begin{array}{l}\text { Ensuring as well as maintenance of sustainability } \\
\text { of the systems and sources of water }\end{array}$} & $\begin{array}{c}\text { Pearson } \\
\text { Correlation }\end{array}$ & $.684^{* *}$ \\
\hline & Sig. (2-tailed) & 0.000 \\
\hline & $\mathrm{N}$ & 5000 \\
\hline \multirow{3}{*}{$\begin{array}{l}\text { Tackling the problem of water quality in affected } \\
\text { habitations }\end{array}$} & $\begin{array}{l}\text { Pearson } \\
\text { Correlation }\end{array}$ & $-.869^{* *}$ \\
\hline & Sig. (2-tailed) & 0.000 \\
\hline & $\mathrm{N}$ & 5000 \\
\hline \multirow{3}{*}{$\begin{array}{l}\text { Preservation of quality of water by } \\
\text { institutionalizing water quality monitoring and } \\
\text { surveillance through a Catchment Area Approach }\end{array}$} & $\begin{array}{l}\text { Pearson } \\
\text { Correlation }\end{array}$ & $.666^{* *}$ \\
\hline & Sig. (2-tailed) & 0.000 \\
\hline & $\mathrm{N}$ & 5000 \\
\hline \multirow{3}{*}{$\begin{array}{l}\text { Undertaking measures to educate masses on the } \\
\text { importance of sanitation and sustainability of } \\
\text { water sources }\end{array}$} & $\begin{array}{l}\text { Pearson } \\
\text { Correlation }\end{array}$ & $.566^{* *}$ \\
\hline & Sig. (2-tailed) & 0.000 \\
\hline & $\mathrm{N}$ & 5000 \\
\hline
\end{tabular}


Correlation Tables of TCPO

\begin{tabular}{|c|c|c|}
\hline & & $\begin{array}{l}\text { Roles of Town and Country } \\
\text { Planning Department in } \\
\text { water resource management }\end{array}$ \\
\hline \multirow{3}{*}{$\begin{array}{l}\text { Roles of Town and Country Planning organization } \\
\text { in water resource management }\end{array}$} & $\begin{array}{c}\text { Pearson } \\
\text { Correlation }\end{array}$ & 1 \\
\hline & $\begin{array}{l}\text { Sig. }(2- \\
\text { tailed) }\end{array}$ & \\
\hline & $\mathrm{N}$ & 5000 \\
\hline \multirow{3}{*}{$\begin{array}{l}\text { Operation and maintenance of three important } \\
\text { benchmarks identified by the GOI- water supply, } \\
\text { sanitation and solid waste management }\end{array}$} & $\begin{array}{c}\text { Pearson } \\
\text { Correlation }\end{array}$ & $.637^{* *}$ \\
\hline & $\begin{array}{l}\text { Sig. (2- } \\
\text { tailed) }\end{array}$ & 0.000 \\
\hline & $\mathrm{N}$ & 5000 \\
\hline \multirow{3}{*}{$\begin{array}{l}\text { Contribution in eliminating key areas like open } \\
\text { defecation and manual scavenging }\end{array}$} & $\begin{array}{c}\text { Pearson } \\
\text { Correlation } \\
\end{array}$ & $-.821^{* *}$ \\
\hline & $\begin{array}{l}\text { Sig. (2- } \\
\text { tailed) }\end{array}$ & 0.000 \\
\hline & $\mathrm{N}$ & 5000 \\
\hline \multirow{3}{*}{$\begin{array}{l}\text { Conducting regular field visits to understand the } \\
\text { development taking place and the actual scenario }\end{array}$} & $\begin{array}{l}\text { Pearson } \\
\text { Correlation }\end{array}$ & $.385^{* *}$ \\
\hline & $\begin{array}{l}\text { Sig. (2- } \\
\text { tailed) }\end{array}$ & .000 \\
\hline & $\mathrm{N}$ & 5000 \\
\hline \multirow{3}{*}{$\begin{array}{l}\text { Regular maintenance of technical options of water } \\
\text { supply and management like small bore sewerage, } \\
\text { simplified sewerage with decentralized waste water } \\
\text { treatment, and mixed sanitation }\end{array}$} & $\begin{array}{l}\text { Pearson } \\
\text { Correlation }\end{array}$ & $.367^{* *}$ \\
\hline & $\begin{array}{l}\text { Sig. (2- } \\
\text { tailed) }\end{array}$ & .000 \\
\hline & $\mathrm{N}$ & 5000 \\
\hline
\end{tabular}

Correlation Table of NGOs

\begin{tabular}{|c|c|c|}
\hline & & $\begin{array}{l}\text { Roles of NGOs in the area's water } \\
\text { resource management }\end{array}$ \\
\hline \multirow{3}{*}{$\begin{array}{l}\text { Roles of NGOs in the area's water } \\
\text { resource management }\end{array}$} & $\begin{array}{c}\text { Pearson } \\
\text { Correlation }\end{array}$ & 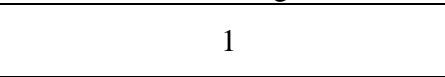 \\
\hline & Sig. (2-tailed) & \\
\hline & $\mathrm{N}$ & 5000 \\
\hline \multirow{3}{*}{$\begin{array}{l}\text { Imparting practical knowledge about } \\
\text { local situations related to water }\end{array}$} & $\begin{array}{l}\text { Pearson } \\
\text { Correlation } \\
\end{array}$ & $.917^{* *}$ \\
\hline & Sig. (2-tailed) & 0.000 \\
\hline & $\mathrm{N}$ & 5000 \\
\hline \multirow{3}{*}{$\begin{array}{l}\text { Have developed the experience on } \\
\text { independent research of local water } \\
\text { and health problems }\end{array}$} & $\begin{array}{l}\text { Pearson } \\
\text { Correlation }\end{array}$ & $.393^{* *}$ \\
\hline & Sig. (2-tailed) & .000 \\
\hline & $\mathrm{N}$ & 5000 \\
\hline \multirow{3}{*}{$\begin{array}{c}\text { Inform the locales about water related } \\
\text { problems and water resource } \\
\text { management }\end{array}$} & $\begin{array}{l}\text { Pearson } \\
\text { Correlation } \\
\end{array}$ & $.757^{* *}$ \\
\hline & Sig. (2-tailed) & 0.000 \\
\hline & $\mathrm{N}$ & 5000 \\
\hline \multirow{3}{*}{$\begin{array}{l}\text { Imparting technical solutions and } \\
\text { alternatives to improve the situation }\end{array}$} & $\begin{array}{l}\text { Pearson } \\
\text { Correlation } \\
\end{array}$ & $.095^{* *}$ \\
\hline & Sig. (2-tailed) & .000 \\
\hline & $\mathrm{N}$ & 5000 \\
\hline
\end{tabular}




\begin{tabular}{|c|c|c|}
\hline \multirow{3}{*}{$\begin{array}{l}\text { Have developed expertise on } \\
\text { implementation of low cost, } \\
\text { environmentally sustainable, and } \\
\text { efficient technologies }\end{array}$} & $\begin{array}{c}\text { Pearson } \\
\text { Correlation }\end{array}$ & $.629^{* *}$ \\
\hline & Sig. (2-tailed) & 0.000 \\
\hline & $\mathrm{N}$ & 5000 \\
\hline \multirow{3}{*}{$\begin{array}{l}\text { Empowering women to act for } \\
\text { improving the access to safe water and } \\
\text { manage water resources }\end{array}$} & $\begin{array}{c}\text { Pearson } \\
\text { Correlation }\end{array}$ & $.760^{* *}$ \\
\hline & Sig. (2-tailed) & 0.000 \\
\hline & $\mathrm{N}$ & 5000 \\
\hline
\end{tabular}

Correlation Table of Private Players

\begin{tabular}{|c|c|c|}
\hline & & $\begin{array}{c}\text { Roles of Private Water } \\
\text { Suppliers }\end{array}$ \\
\hline \multirow{3}{*}{ Roles of Private Water Suppliers } & $\begin{array}{l}\text { Pearson } \\
\text { Correlation }\end{array}$ & 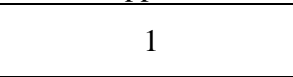 \\
\hline & Sig. (2-tailed) & \\
\hline & $\mathrm{N}$ & 5000 \\
\hline \multirow{3}{*}{$\begin{array}{l}\text { Is its service required frequently by the } \\
\text { residents? }\end{array}$} & $\begin{array}{c}\text { Pearson } \\
\text { Correlation } \\
\end{array}$ & $.942^{* *}$ \\
\hline & Sig. (2-tailed) & 0.000 \\
\hline & $\mathrm{N}$ & 5000 \\
\hline \multirow{3}{*}{$\begin{array}{l}\text { Does it provide adequate supply of water to } \\
\text { each household? }\end{array}$} & $\begin{array}{l}\text { Pearson } \\
\text { Correlation }\end{array}$ & $.430^{* *}$ \\
\hline & Sig. (2-tailed) & .000 \\
\hline & $\mathrm{N}$ & 5000 \\
\hline \multirow{3}{*}{$\begin{array}{c}\text { Even distribution of water among all the } \\
\text { residents }\end{array}$} & $\begin{array}{l}\text { Pearson } \\
\text { Correlation }\end{array}$ & $.300^{* *}$ \\
\hline & Sig. (2-tailed) & .000 \\
\hline & $\mathrm{N}$ & 5000 \\
\hline \multirow{3}{*}{$\begin{array}{l}\text { Does the organization address water leakage } \\
\qquad \text { (if any)? }\end{array}$} & $\begin{array}{l}\text { Pearson } \\
\text { Correlation } \\
\end{array}$ & $.332^{* *}$ \\
\hline & Sig. (2-tailed) & .000 \\
\hline & $\mathrm{N}$ & 5000 \\
\hline \multirow{3}{*}{$\begin{array}{l}\text { Is the organization aware of water resource } \\
\text { management? }\end{array}$} & $\begin{array}{l}\text { Pearson } \\
\text { Correlation }\end{array}$ & $.798^{* *}$ \\
\hline & Sig. (2-tailed) & 0.000 \\
\hline & $\mathrm{N}$ & 5000 \\
\hline \multirow{3}{*}{$\begin{array}{l}\text { Does the organization develop infrastructure } \\
\text { or technical solution to ensure minimal } \\
\text { leakage of water during distribution? }\end{array}$} & $\begin{array}{c}\text { Pearson } \\
\text { Correlation }\end{array}$ & $-.710^{* *}$ \\
\hline & Sig. (2-tailed) & 0.000 \\
\hline & $\mathrm{N}$ & 5000 \\
\hline \multirow{3}{*}{$\begin{array}{c}\text { Does the organization ensure steps to } \\
\text { harvest rain water? }\end{array}$} & $\begin{array}{l}\text { Pearson } \\
\text { Correlation }\end{array}$ & $-.389^{* *}$ \\
\hline & Sig. (2-tailed) & .000 \\
\hline & $\mathrm{N}$ & 5000 \\
\hline
\end{tabular}




\section{APPENDIX 2: QUALITATIVE QUESTIONNAIRE Challenges of Water Management System}

1. What are the challenges you are facing to execute water management operation?

2. What are the reasons for failure in water management system? Rate the following statements on the scale of $1-5$ where strongly agreed $=1$, Agree $=2$, No comments $=3$, Disagreed $=4$, strongly disagreed $=5$.

\begin{tabular}{|c|c|c|c|c|c|}
\hline & & & & \\
\hline $\begin{array}{c}\text { The reasons for failure of water resource authority } \\
\text { are insufficient human resource; poor operation and } \\
\text { maintenance activities; and unused instruments and } \\
\text { devices. }\end{array}$ & & & & & \\
\hline Poor infrastructure is responsible for water crisis. & & & & & \\
\hline $\begin{array}{c}\text { Lack of coordination between public demand and } \\
\text { officials' expertise hamper water supply as well as } \\
\text { water resource management system. }\end{array}$ & & & & & \\
\hline Investment of private enterprise is necessary. & & & & & \\
\hline $\begin{array}{c}\text { Water resource management can be developed by } \\
\text { improving policy, strategic planning, and legal } \\
\text { framework. }\end{array}$ & & & & & \\
\hline $\begin{array}{c}\text { Government budget allocation and revenues of this } \\
\text { department must be compared. }\end{array}$ & & & & & \\
\hline $\begin{array}{c}\text { Challenges of water resource management are not } \\
\text { identified till now. }\end{array}$ & & & & & \\
\hline
\end{tabular}

\section{APPENDIX 3: QUANTITATIVE QUESTIONNAIRE}

\section{Section A: Demographic Profile}

1. Age
a) $18-28$ years
b) 29-39 years
c) $40-50$ years
d) Above 50

2. Gender

a) Male

b) Female 
3. Educational Qualification
a) Below $10^{\text {th }}$ Standard
b) $10^{\text {th }}$ Standard
c) $12^{\text {th }}$ Standard
d) Graduate
e) Post Graduate
f) PHD

4. Years of stay at Bhopal
a) Less than 5 years
b) 5-8 years
c) 9-12 years
d) More than 12 years

5. Family Size
a) $2-5$
b) $6-8$
c) More than 8

6. Source of Income
a) Service in Government Organization
b) Service in Private Organization
c) Self-employed

7. Income level per annum
a) Less than Rs. 200000/-
b) Rs. 200000/-Rs. 500000/
c) Rs. 500000/-Rs. 800000/
d) Above Rs. 800000/-

8. Ownership of house

a) Own house

b) Rented house

\section{Section B: General Background of Citizens}

9. Resources of water supply system
a) Tube well
b) Municipality water
c) Water pump

10 . Water consumption per day of your family
a) 20-50 liters
b) 50-80 liters
c) $80-110$ liters
d) 110- 140 liters 
e) $140-170$ liters

f) More than 170 liters

11. What is the priority for water resources?
a) Domestic use
b) Industry
c) Energy
d) Environment
e) Growing cities

12. Are you satisfied with the water supply system of your city?

a) Yes (If 'Yes', go to question no 13, 14, 15, 16)

b) No (If 'No', go to Q. 17, 18, 19)

13. Who are the resource persons to resolve water crisis in your locality?
a) Municipal Corporation
b) MLAs
c) NGOs
d) Local body

14. Do you really get the assistance for water resource problem?
a) Yes
b) No

15. Is there any helpline provided for the crisis period?
a) Yes
b) No

16. Does Helpline work for you 24/7?
a) Yes
b) No
c) Not sure

17. How to develop water resource management in your area?
a) Proper distribution of water
b) Developing people awareness level
c) Developing waste management system
d) The electricity bill must be different for domestic use and industrial use
e) All of the above

18. What are the threats related to resources?
a) Floods
b) Draught
c) Water scarcity and quality in surface water
d) Water scarcity and quality in groundwater
e) Poor management system
f) Lack of co-ordination between stakeholders (BMC \& PHE) 
19. How can we manage water resources?
a) Through monitoring the resource
b) Through knowledge sharing
c) Infrastructural development (rainwater harvesting for example)
d) Increased productive efficiency related to water usage (e.g. agriculture, irrigation)
e) Waste water treatment
f) Public participation
g) All of the above

\section{Section C: Water Management Strategies at Bhopal}

20. Capacity building for water resource management is possible through
a) Human Resource Development
b) Organizational change
c) Directive reforms
d) Cumulative participation of the three

21. Do you participate in any initiative of sustainable water management program?
a) Mostly participate
b) Somewhat participate
c) Moderately participate
d) Rarely participate
e) Very rarely participate

22. Do you contribute in sustainable water management initiative in your area? Rate your initiative as strongly agree $=1$, Agree $=2$, No comments $=3$, Disagree $=4$, strongly disagree $=5$.

\begin{tabular}{|c|c|c|c|c|c|}
\hline I turn off the water while I brush my teeth with toothpaste & 1 & 2 & 3 & 4 & 5 \\
\hline \multicolumn{6}{|l|}{ I use water conservatively while taking bath. } \\
\hline $\begin{array}{c}\text { I try and avoid littering in nearby lakes and save the aquatic } \\
\text { habitat. }\end{array}$ & & & & & \\
\hline I avoid the practice of water wastage. & & & & & \\
\hline $\begin{array}{l}\text { I like to preserve the rain and fresh water which is helpful during } \\
\text { my household chore. }\end{array}$ & & & & & \\
\hline I always repair the leaky faucets in home within minimum time & & & & & \\
\hline $\begin{array}{l}\text { I have been a participant in sustainable water management } \\
\text { program, and assisted the group in water level monitoring. }\end{array}$ & & & & & \\
\hline
\end{tabular}

23. Do you feel any impact of your initiatives towards sustainable water management?
a) Strongly agree
b) Agree
c) Neutral
d) Disagree
e) Strongly disagree 
24. What according to you should be done to improve the impact and reduce water crisis in your area? Rate the following statements on scale of 1-5 where, strongly agree $=5$, Agree $=4$, No comments $=3$, Disagree $=2$, strongly disagree $=1$.

\begin{tabular}{|c|l|l|l|l|l|}
\hline $\begin{array}{c}\text { Factual knowledge and skill will help to handle } \\
\text { water resource management system. }\end{array}$ & & & & & \\
\hline $\begin{array}{c}\text { Understanding of surface water and underground } \\
\text { water enable the person to convince other people } \\
\text { regarding the resolve of water crisis. }\end{array}$ & & & & & \\
\hline $\begin{array}{c}\text { Water literacy must be provided with the help of } \\
\text { civil society. }\end{array}$ & & & & & \\
\hline $\begin{array}{c}\text { Motivational programs should be initiated which } \\
\text { can improve sustainable water management }\end{array}$ & & & & & \\
\hline
\end{tabular}

\section{Section D: Roles of NGOs in the Area's Water Resource Management}

The following questions are based on 5-point Likert scale where $\mathbf{1}$ mean strongly agree and 5 means strongly disagree, with 3 being No comments.

\begin{tabular}{|c|l|l|l|l|l|}
\hline $\begin{array}{c}\text { Imparting practical knowledge about local situations } \\
\text { related to water }\end{array}$ & & & & & 5 \\
\hline $\begin{array}{c}\text { Have developed the experience on independent } \\
\text { research of local water and health problems }\end{array}$ & & & & & \\
\hline $\begin{array}{c}\text { Inform the locales about water related problems and } \\
\text { water resource management }\end{array}$ & & & & & \\
\hline $\begin{array}{c}\text { Imparting technical solutions and alternatives to } \\
\text { improve the situation }\end{array}$ & & & & & \\
\hline $\begin{array}{c}\text { Have developed expertise on implementation of low } \\
\text { cost, environmentally sustainable, and efficient } \\
\text { technologies }\end{array}$ & & & & & \\
\hline $\begin{array}{c}\text { Empowering women to act for improvement of the } \\
\text { access to safe water and manage water resources. }\end{array}$ & & & & & \\
\hline
\end{tabular}

\section{Section E: Roles of Bhopal Municipal Corporation}

The following questions are based on 5-point Likert scale where $\mathbf{1}$ mean strongly agree and $\mathbf{5}$ means strongly disagree, with 3 being No comments.

\begin{tabular}{|c|c|c|c|c|c|}
\hline & 1 & 2 & 3 & 4 & 5 \\
\hline \multicolumn{6}{|l|}{$\begin{array}{l}\text { Ensures the provision of pure water (drinking purposes) } \\
\text { with appropriate flow pressure }\end{array}$} \\
\hline \multicolumn{6}{|l|}{ Control the scarce water resources } \\
\hline \multicolumn{6}{|l|}{ Ensure adequate water supply for domestic use } \\
\hline \multicolumn{6}{|l|}{ Construction of irrigation structures in irrigation areas } \\
\hline \multicolumn{6}{|l|}{$\begin{array}{l}\text { Appropriate water allocation to each household in the } \\
\text { locale }\end{array}$} \\
\hline \multicolumn{6}{|l|}{ Construction of water treatment plant } \\
\hline $\begin{array}{l}\text { Increased productive efficiency related to water usage } \\
\text { (e.g. agriculture, irrigation) }\end{array}$ & & & & & \\
\hline $\begin{array}{c}\text { Infrastructural development (rainwater harvesting, } \\
\text { prevention of flood, for example) }\end{array}$ & & & & & \\
\hline
\end{tabular}




\section{Section F: Roles of Private Water Suppliers}

The following questions are based on 5-point Likert scale where $\mathbf{1}$ mean strongly agree and 5 means strongly disagree, with 3 being No comments.

\begin{tabular}{|c|l|l|l|l|l|}
\hline & 1 & 2 & 3 & 4 & 5 \\
\hline Is its service required frequently by the residents? & & & & & \\
\hline $\begin{array}{c}\text { Does it provide adequate supply of water to each } \\
\text { household? }\end{array}$ & & & & & \\
\hline $\begin{array}{c}\text { Do you provide adequate supply of water to each } \\
\text { household? }\end{array}$ & & & & & \\
\hline Even distribution of water among all the residents & & & & & \\
\hline $\begin{array}{c}\text { Does your organization address water leakage (if } \\
\text { any)? }\end{array}$ & & & & & \\
\hline $\begin{array}{c}\text { Is your organization aware of water resource } \\
\text { management? }\end{array}$ & & & & & \\
\hline $\begin{array}{c}\text { Does your organization develop infrastructure or } \\
\text { technical solution to ensure minimal leakage of } \\
\text { water during distribution? }\end{array}$ & & & & & \\
\hline $\begin{array}{c}\text { Does your organization ensure steps to harvest rain } \\
\text { water? }\end{array}$ & & & & & \\
\hline
\end{tabular}

\section{Section G: Roles of Public Health Engineering Department in Water supply and management}

The following questions are based on 5-point Likert scale where 1 mean strongly agree and 5 means strongly disagree, with 3 being No comments.

\begin{tabular}{|c|l|l|l|l|l|}
\hline $\begin{array}{c}\text { Full coverage of both rural and urban population } \\
\text { with safe drinking water supply facilities }\end{array}$ & & & & & 5 \\
\hline $\begin{array}{c}\text { Coverage of urban and rural population with } \\
\text { sanitation, up to the limit determined by the GOI, } \\
1981\end{array}$ & & & & & \\
\hline $\begin{array}{c}\text { Ensuring as well as maintenance of sustainability of } \\
\text { the systems and sources of water. }\end{array}$ & & & & & \\
\hline $\begin{array}{c}\text { Tackling the problem of water quality in affected } \\
\text { habitations }\end{array}$ & & & & & \\
\hline $\begin{array}{c}\text { Preservation of quality of water by institutionalizing } \\
\text { water quality monitoring and surveillance through a } \\
\text { Catchment Area Approach }\end{array}$ & & & & & \\
\hline $\begin{array}{c}\text { Undertaking measures to educate masses on the } \\
\text { importance of sanitation and sustainability of water } \\
\text { sources. }\end{array}$ & & & & & \\
\hline
\end{tabular}




\section{Section H: Roles of Town and Country Planning Department in Water} Resource Management

The following questions are based on 5-point Likert scale where $\mathbf{1}$ mean strongly agree and 5 means strongly disagree, with 3 being No comments.

\begin{tabular}{|c|l|l|l|l|l|}
\hline $\begin{array}{c}\text { Operation and maintenance of three important } \\
\text { benchmarks identified by the GOI- water supply, } \\
\text { sanitation, and solid waste management }\end{array}$ & & & & & \\
\hline $\begin{array}{c}\text { Contribution in eliminating key areas like open } \\
\text { defecation and manual scavenging }\end{array}$ & & & & & \\
\hline $\begin{array}{c}\text { Conducting regular field visits to understand the } \\
\text { development taking place and the actual scenario }\end{array}$ & & & & & \\
\hline $\begin{array}{c}\text { Regular maintenance of technical options of water } \\
\text { supply and management like, small bore sewerage, } \\
\text { simplified sewerage with decentralized wastewater } \\
\text { treatment, and mixed sanitation. }\end{array}$ & & & & & \\
\hline
\end{tabular}

Any other comments

Thank you for your time! 